\title{
Review
}

\section{The First Amendment in Theory and Practice}

\section{Robert Allen Sedler†}

The System of Freedom of Expression. By Thomas I. Emerson. New York: Random House, 1970. Pp. ix, 728. $\$ 20.00$ (clothbound), $\$ 3.95$ (paperback).

The only way to describe The System of Freedom of Expression is to say that it is in every sense a master work of scholarly excellence. Professor Emerson has brought together his years of experience and extensive researches into the area of freedom of expression and has fashioned a comprehensive work that, in my opinion, must serve as a starting point for any further exploration of the subject. He has indeed developed freedom of expression as a system, setting forth its underlying legal postulates and demonstrating its application over the wide range of what may be called "First Amendment problems."

It is Professor Emerson's submission that "[t] about the First Amendment today is that the Supreme Court has never developed any comprehensive theory of what that constitutional guarantee means and how it should be applied in concrete cases," and that its failure to do so "has had a most unfortunate effect upon the work of the lower Federal and State Courts, upon the performance of government officials, and upon the understanding of the public." 1 In a sense the book is "addressed" to the Supreme Court, which, in his view, must perform the largely unfulfilled task of "building a comprehensible structure of doctrine and practice that is meaningful to all and meets the needs of a free society." 2 It is the "basic legal structure of the system" that is the subject matter of the book.

Freedom of expression in a democratic society, says Professor Emerson, rests upon four premises. Such freedom is: (1) essential as a means of assuring individual self-fulfillment; (2) an essential process for ad-

† Professor of Law, University of Kentucky. B.A. 1956, J.D. 1959, University of Plttsburgh.

1. T. EMERSON, THE SYSTEM OF FREEDOM OF EXPRESSION 15-16 (1970) [hereinafter cited to page number only]. See also the discussion at pp. 717-20.

2. P. 721 . 
vancing knowledge and discovering truth; (3) essential to provide for participation in decision-making by all members of the society; ( 4 ) a method of achieving a more adaptable and hence a more stable community, of maintaining the precarious balance between healthy cleavage and necessary consensus. ${ }^{3}$ These premises mean that freedom of expression is a good in itself; other societal objectives, such as public order, must therefore be achieved by means other than the suppression of expression such as counter-expression and the regulation or control of conduct.4 The conflict between freedom of expression and other values, he points out, has revolved around what limitations, if any, ought to be imposed upon freedom of expression in order to reconcile that interest with other individual and social interests sought by the good society. ${ }^{5}$

It is this concept of limitations on freedom of expression that Professor Emerson challenges. He maintains that freedom of expression must be given full protection and that other societal values may be suffciently advanced by putting restraints upon conduct or action that does not constitute expression, thereby reconciling freedom of expression with other values rather than limiting it. The expression-action distinction is thus crucial to his thesis and to the underlying theory of the system of freedom of expression. Since expression is to receive full protection, it must be protected "against government curtailment at all points, even where the results of the expression may appear to be in conflict with other social interests that the government is charged with safeguarding." "balance" the interest in freedom of expression against other social interests, ${ }^{7}$ but to define expression and the other key elements of "abridge" and "law" that are contained in the First Amendment. These elements must be defined in a functional manner derived from the basic considerations upon which the system of freedom of expression is premised. ${ }^{8}$ Expression is defined, of course, by distinguishing it from action, and when "expression-action" elements are

3. Pp. 6-7.

4. P. 8.

5. P. 9.

6. P. 17 .

7. Professor Emerson says that insofar as the Supreme Court has developed any general theory of the First Amendment, it has been the "ad hoc balancing" formula. Pp. 717-18. In addition to criticizing the theoretical feasibility of the "balancing" test Emerson contends that even its proponents cannot apply it in practice in a comprehensive way. See p. 718.

8. P. 17. 
combined, the test is whether expression or action is the "dominant element."

Different legal doctrines, derived from these definitions, apply to different kinds of protection which legal institutions must provide for a system of freedom of expression. Professor Emerson sees most of the issues as falling into three categories. First and foremost, there is protection of the individual's right to freedom of expression against interference by the government in its efforts to achieve other social objectives or to advance its own interest. This has been the chief area of legal controversy, and here, he says, the problem is one of distin. guishing "expression" from "action" and giving full protection to expression. Where the governmental regulation affects conduct consisting of both action and expression, the regulation must be drawn in such a way as to restrict only the action, leaving the expression un. impaired. ${ }^{10}$

Second, there is the fashioning of controls within the system of freedom of expression itself in order to regulate conflicts between individuals and groups within that system, to protect individuals and groups from non-governmental interference, and to promote effective functioning of the system. The question in this area is whether there has been an "abridgement" of freedom of expression, and it is necessary to formulate specific rules for mutual accommodation of participants in the system, fairness in the allocation of scarce facilities and assurances that the system will be expanded rather than contracted. ${ }^{11}$ Third, the restriction of the government itself is necessary insofar as it participates in the system of expression, because of the special protection needed by the system against the special character of government expression.12 Finally, Professor Emerson excludes certain sectors of conduct from the "main system," such as certain aspects of the operation of the military, of commercial activities, of the activities of children and of communication with foreign countries. In these activities, he says, the functions of expression are different, and different legal rules may be required. ${ }^{13}$

9. P. 18. Professor Emerson's "expression-action" formulation is something very different from the "pure speech-symbolic speech" distinction favored, for example, by Justice Black. See the discussion at p. 719 .

10. Pp. 18-19.

11. P. 19 .

12. Id. Other legal doctrines are necessary to resolve particular problems such as the places where First Amendment rights may be exercised and the relationship of the system of freedom of expression to the system of privacy. Such issues, in his view, must be resolved "on a functional basis, taking into account the objectives and operations of the system."

13. Pp. 19-20. I cannot agree with Professor Emerson's exclusion of "certain aspects of 
Having developed the underlying postulates of his system, Professor Emerson proceeds to analyze what may be called the "substantive areas of expression," that is, the functional situations where "First Amendment problems" have arisen. He delineates the constitutional issues in each area, explains in detail how they have been treated by the Supreme Court, indicates often how they would be resolved under different tests such as "balancing," "clear and present danger," and "incitement," and finally resolves them under his full protection approach. It is clear that the full protection approach, as applied by Professor Emerson, would frequently lead to different results than have been reached by the Supreme Court. We may consider some illustrations.

The "draft card burning" case of United States $v . O^{\prime} B$ rien," in my opinion, demonstrates most clearly the difference in result between the "full protection" and "balancing" approaches to freedom of expression. The case also highlights the contrast between the "pure speech-symbolic speech" distinction favored by the Supreme Court and Professor Emerson's "expression-action" formulation. The Supreme Court treated O'Brien's action as "symbolic speech," and observed that where speech and non-speech elements were combined in the same course of conduct," "[a] sufficiently important governmental interest in regulating the non-speech element can justify incidental limitations on First Amendment freedoms."1s It found that such a governmental interest was present there and concluded-in total disregard of the legislative history and the circumstances surrounding the enactment of the 1965 amendment to the Selective Service Act-that the governmental interest was "unrelated to the suppression of freedom of expression." O'Brien's conviction was affirmed. Professor Emerson's analysis is quite different. As he points out: "The burning of a draft card is, of course, conduct that involves both communication and physical acts. Yet it seems quite clear that the predominant element

the operations of the military" from the main system. I see no reason why persons in military service should not have the same kind of First Amendment rights as persons in civilian life or why the military "Establishment" should be able to impose restrictions on the frecdom of servicemen to receive information and to discuss military and political matters. The need for "obedience," "discipline," "combat readiness," and the like, which has traditionally been asserted to justify the distinction, seems to me to be entitled to no greater weight than other societal interests such as the maintenance of public order. If those societal interests, in Professor Emerson's view, should not be balanced against the interest in freedom of expression, it is difficult to see why the interest in "effectively waging war" should be. As to the situation in practice, see generally Sherman, The Military Courts and Servicemen's First Amendment Rights, 22 HAstiNas I.J. 325 (1971).

14. 391 U.S. 367 (1968).

15. Id. at $376-77$. 
in such conduct is expression (opposition to the draft) rather than action (destruction of a piece of cardboard). The registrant is not concerned with secret or inadvertent burning of his draft card, involving no communication with other persons. The main feature, for him, is the public nature of the burning, through which he expresses to the community his ideas and feelings about the war and the draft."10 Since the burning of a draft card constitutes expression under this formulation, the full protection approach could lead only to the conclusion that O'Brien's act was constitutionally protected. ${ }^{17}$

The full protection approach would invalidate sedition laws, in their entirety, including those laws prohibiting "knowing advocacy of force and violence."18 The permissible line of governmental intervention would be drawn only at the point where action actually began.19 It would deny legislative investigating committees the power to make any inquiry into conduct classifiable as expression. ${ }^{20}$ It would protect picketing "in or near a courthouse"21 and peaceful demonstrations on the grounds of a county jail.22 It would invalidate "race libel" ${ }^{23}$ and criminal libel laws. ${ }^{24}$ It would protect all "incitement" except when it reached the point of action, such as specific instructions to commit immediate particular acts of violence. ${ }^{25}$ It would return "obscenity" to the protection of the First Amendment without regard to its "hard core" nature except for "obscene conduct" that can be classified as "action," and except for restrictions on "thrusting" obscene material before others against their will or disseminating it to children. ${ }^{26}$ It would eliminate the "New York Times test" 27 of tort liability

16. P. 84 .

17. Pp. 85-86. See also Professor Emerson's discussion of "flag desccration" at pp. 87.88. The Supreme Court has been unable to resolve the issue of symbolic speech. See Strect $v_{0}$ New York, 394 U.S. 576 (1969), avoiding the issue, and Radich v. New York, 91 S. Ct. 1217 (1971), affirming a conviction for flag desecration by an equally-divided Court, Justicc Douglas not participating.

18. Compare Scales v. United States, 367 U.S. 203 (1961), with Dennis v. United States, 341 U.S. 494 (1951).

19. Pp. 126, 160 .

20. Pp. 277.79.

21. Cf. Cox v. Louisiana, 379 U.S. 559 (1965).

22. Cf. Adderley v. Florida, 385 U.S. 39 (1966).

23. Cf. Beauharnais v. Illinois, 343 U.S. 250 (1952).

24. Cf. Garrison v. Louisiana, 379 U.S. 64 (1964).

25. Cf. People v. Epton, 19 N.Y.2d 496, 227 N.E.2d 829 (1967), cert. denied, 890 U.S. 29 (1968). Professor Emerson's position is set forth at pp. 335.36.

26. See pp. 495-97. I strongly disagree with the "thrusting" exception and have rescrvations about "protecting" children from the "baneful effects" of obscenity. Conceding the sexual "hang-up" existing in this society, I still see no justification in singling out sexual expression for separate treatment.

27. See New York Times v. Sullivan, 376 U.S. 254 (1964). 
for defamation and invasion of privacy, ${ }^{28}$ and would deny recovery except for a "very narrow area in which disclosure of embarrassing facts about a person or fictionalization of matter concerning him would fall within the protection of the privacy system,"29 that is, would violate what Professor Emerson finds to be the constitutional right of privacy. ${ }^{30}$ It would hold unconstitutional the provisions of the Hatch Act ${ }^{31}$ that make political eunuchs out of civil service employees.33 And it would invalidate the Federal Anti-Riot Act of $1968^{33}$ on the ground that it "seeks to punish conduct that never gets beyond the state of expression."34

All in all, the full protection approach proposed by Professor Emerson as the underlying basis of the system of freedom of expression would serve well the purpose for which it was intended-to give full protection to the expression of ideas. Professor Emerson carefully draws the line between expression and action in such a way as to restrict severely the power of the government to repress expression under the guise of "regulating action." The "action" that he would exclude from the First Amendment's protection generally involves the kind of conduct that most libertarians would concede to be "beyond the pale," such as shouted commands to a mob engaged in acts of violence, a personal face to face insult inviting retaliation, shouting dorvn a speaker, or violent picketing. And when it comes to the application of the expression-action formulation to particular cases, I find that my disagreements with Professor Emerson are very few indeed.35 The system of freedom of expression that Professor Emerson has developed then, and the expression-action formulation on which it is based,

28. The test was extended to fictionalized portrayal, included in New York's invasion of privacy law, in Time, Inc v. Hill, 385 US. 374 (1967).

29. P. 556.

30. See pp. 544-48.

31. 5 U.S.C. \& 7324.

32. In United Public Workers v. Mitchell, 330 U.S. 75 (1947), a divided Court upheld the constitutionality of the Act.

33. 18 U.S.C. $\$ \$ 2101-2102$.

34. P. 408. The constitutionality of the Act "on its face" was upheld in National Mobilization Committee to End the War in Viet Nam v. Foran, 411 F.2d 934 (7th Cir. 1969), and will be considered again in the appeal from convictions of the "Chiago seren." United States v. Dellinger, No. 69 CR 180 (N.D. IIl., jury verdict Feb. 15, 1970), appeal doclieted, No. 18295 (7th Cir., Feb. 21, 1970).

35. One area in which I may have some disagreement is that of "expression uttered in the context of a public assembly which may lead to violence or disorder." See the discussion at pp. 328-336. I would, I think, protect all public statements made during "riot conditions" even if they constituted "specific instructions to commit immediate particular acts of violence." I would draw the line only at "one-to-one" solicitation or at "group instruction" where the acts of violence did in fact result and a causal connection conld be established. 
represent a comprehensive and consistently valid theory as to the mean* ing of the First Amendment.

My reservations about Professor Emerson's system, and particularly about the expression-action formulation, go precisely to what I consider to be its theoretical nature. In a society which in practice, as well as in theory, held freedom of expression to be a primary value and a "good in itself," and which in fact accepted the premises upon which Professor Emerson's system of freedom of expression is founded, these reservations would not exist. In this kind of society there would be a correlation between theory and practice, and between the theoretical solution proposed by Professor Emerson and the administration of "the system" by those who staff the courts and hold the reins of governmental power. But I do not believe that we live in such a society or that we are likely to do so in the foreseeable future. I do not believe -conventional wisdom and judicial pronouncements to the contrary notwithstanding-that freedom of expression is a high value in this society. I do not believe that it is considered a "good in itself." And, therefore, I believe that, "the structure of the system of freedom of expression," if it is to be effective in protecting that freedom in practice, must take account of this unpleasant reality and adapt itself to it. Let me proceed to develop this point more fully.

Professor Emerson has clearly pointed out the dangers that exist to freedom of expression in this or in any other society, warning us that "it is necessary to recognize the powerful forces that impel men towards the elimination of unorthodox expression." ${ }^{36} \mathrm{He}$ goes on to say:

Most men have a strong inclination, for rational or irrational reasons, to suppress opposition. On the other hand, persons who stand up against society and challenge the traditional view usually have similarly strong feelings about the issues they raise. Thus dissent often is not pitched in conventional terms, nor does it follow customary standards of polite expression. Moreover, the forces of inertia within a society ordinarily resist the expression of new ideas or the pressures of the underprivileged who seek a change. And the longer-run logic of the traditional theory may not be immediately apparent to untutored participants in the conflict. Suppression of opinion may thus seem an entirely plausible course of action; tolerance a weakness or a foolish risk. ${ }^{37}$

He makes a number of other points along these lines. In order to

36. P. 9.

37. Pp. 9-10. 
maintain a system of freedom of expression, he says, the members of the society must be willing to sacrifice individual and short-term advantage for social and long-range goals. The process must operate in a context that is charged with emotion and subject to powerfully conflicting forces of self-interest. Those who favor "precise limitations" on expression find it difficult to define and maintain precision, because the fear is of the consequences rather than of the expression itself; the result is that repression of expression, like all preventive measures, cuts far more widely and deeply than is necessary to control the ensuing conflict. He also points out that the necessary imprecision of the limitations allows a wide area of expression to be brought within their reach, and places enormous discretionary power in the hands of those who administer them. And these limitations will be enforced by the government itself, bringing into play not only "administrative extremes," but the opportunity to distort the limitations and use them for ulterior purposes. Finally, limitations are usually applied in an atmosphere of public fear and hysteria, which puts intense pressures on the doctrines and the institutions to enforce the limitations, ${ }^{38}$ and the very enforcement of the limitations upon some persons or groups creates a "chilling effect" upon the exercise of freedom of expression by others. ${ }^{39}$

It is these considerations, says Professor Emerson, which must be weighed in attempting to construct a theory of limitations. This leads him to the conclusion that: "A system of free expression can be successful only when it rests upon the strongest possible commitment to the positive right and the narrowest possible basis for exceptions. And any such exceptions must be clear-cut, precise, and readily controlled. Otherwise the forces that press toward restriction will break through the openings, and freedom of expression will become the exception and suppression the rule."10

The theory of limitations that Professor Emerson has constructed in an effort to avoid these consequences is, as I have noted, formulated in terms of the distinction between expression, which is protected, and action, which is not. It is precisely this formulation which causes me to have serious reservations about the effectiveness of the theory in

38. P. 11. The best example of judicial responsiveness to "public fear and hysteria" in the Cold War context, I think, is Dennis v. United States, 341 U.S. 491 (1951). Nor do I think that the constitutionality of forcibly relocating American citizens because of their racial ancestry could have been upheld except during the days of World War II. Sec Korematsu v. United States, 329 U.S. 214 (1914).

39. Pp. 10-11.

40. P. 10 (emphasis added). 
practice. I fear that in practice this "limitation" will not be "clearcut, precise and readily controlled." It certainly would be if it were applied by Professor Emerson and probably would be if applied by the Supreme Court (and insofar as courts are concerned, it is the Supreme Court that is Professor Emerson's frame of reference). But the world of Professor Emerson and the world of the Supreme Court is not the world in which freedom of expression must be protected on a day-to-day basis. The day-to-day protection of that freedom depends upon the actions of government officials at all levels and upon the positive intervention of state court and lower federal court judges. I would submit that in terms of attitudes toward the value of freedom of expression, the world of Professor Emerson and even the world of the Supreme Court is not the world of government officials, of police and prosecutors, and-if I am allowed to commit heresy-not the world of many state court and lower federal court judges. If $I$ am right in my perception of that world, if I am right in my analysis of the strength -or weakness - of its commitment to freedom of expression, and if I correctly understand the "political-behavioral" component of its institutions and those who administer them, the expression-action formulation, for reasons which I will elaborate on shortly, will not give "full protection" to freedom of expression, even if Professor Emerson's expression-action distinction were to be adopted by the Supreme Court.

My view of the system of freedom of expression and its day-to-day world is a view that comes both "from without and within"-that is, both from an academic analysis of decided cases and legal commentary, and from a lawyer's experience in actual litigation. It is the view of the academician who has attempted to be a "part-time movement lawyer,"41 representing individuals and groups seeking to achieve fundamental social change in their inevitable conflict with the "Establishment" that holds the reins of governmental and societal power. In the process I have litigated a number of freedom of expression cases, successfully and unsuccessfully, ${ }^{42}$ and have viewed a number of

41. There are many varieties of "movement lawyers." Some are full-time employees of "movement" organizations. A larger number are lawyers engaged in private practice who devote considerable time, generally without compensation, to taking such cases. And some, like the present writer, are law professors who venture forth from the "groves of academe." All share one thing in common-they are not popular with their "brothers at the bar" and find themselves involved in disciplinary proceedings far out of proportion to their number. Perhaps they are immoral as a class, but it might be that their ldentification as movement lawyer may have something to do with it. Thus far, most of the attempts to "eliminate" movement lawyers have been unsuccessful. See, e.g., Sobol v. Pcrez, 289 F. Supp. 392 (E.D. La. 1968).

42. For those that have resulted in reported opinions, see McSurely v. Ratlif, 282 F. 
others "from within." Likewise my primary academic interest in the First Amendment area has revolved around the protection of First Amendment rights in practice, and my reference point has been the "behavior" of the state and lower federal courts when called upon to extend such protection. ${ }^{43}$ This participation and involvement on my part has admittedly prevented me from acquiring the perspective of the "dispassionate scholar," but at the same time I believe that it has given me insights into the operation of the legal system that no amount of reading of cases and law review articles and the other traditional tools of scholarship can supply. In any event, it is from this perspective-and with this bias-that I view the effectiveness of the expression-action formulation to protect First Amendment rights in practice.

My analysis of the effectiveness of the expression-action formulation is based first on the separation of the system of freedom of expression into what I consider to be its functional components. Taking together the guarantees of expression, assembly and petition, and relating them to the First Amendment's underlying values and premises, 44 think that there are three functionally very different, although sometimes overlapping, objectives that the First Amendment seeks to achieve. First, and from the political perspective the most important, is what I call the freedom to dissent and to work for social change. Utilizing the guarantees of expression, assembly and petition in their fullest sense, individuals and groups have the right to dissent from the policies pursued by the government. They have the right to try to change those policies and through the democratic process to try to obtain the reins of governmental power for themselves. In short, the First Amendment guarantees the right of peaceful revolution, and the exercise of this right may not be subject to inhibition and repression by those presently possessing governmental power. This component incorporates the third and fourth premises upon which Professor Emerson's system proceeds: namely, that freedom of expression is essential to provide for participation in decision-making by all members of society, and that it is a method of maintaining the "precarious balance between healthy cleavage and

Supp. 848 (E.D. Ky. 1967); Black Unity League of Kentudky v. Mfiller, 394 US. 100 (1969); Honey จ. Goodman, 432 F.2d 333 (6th Cir. 1970); O'Leary v. Commonwealth of Kentucky. 441 S.W.2d 150 (Ky. 1969), appeal dismissed, 396 U.S. 40 (1959), Hetrick v. MIartin, 322 F. Supp. 545 (E.D. Ky. 1971).

43. See Sedler, The Dombrowski-Type Suit as an Efective Weapon for Social Change: Reflections from Without and Within, $18 \mathrm{KAN}$. L. REv. 237, 269 (1970).

44. See Professor Emerson's discussion at pp. 6-7. 
necessary consensus."1s However, it carries these premises a bit further to emphasize that dissent and efforts at social change, no matter how radical and sweeping, are an integral part of a democratic society.

Second, there is what I call the public information function, or as Professor Emerson puts it in his second premise, the function of freedom of expression as an essential process for advancing knowledge and discovering truth. ${ }^{46}$ Recognition of this function requires protecting the dissemination of all expression and ideas, whether or not related to dissent and social change, and in essence involves the societal "right to know." Third, there is the matter of individual expression and association-the right to speak one's mind, to hear others, to belong to groups and associate with others for mutual benefit, ${ }^{47}$ to learn and to enjoy the world of ideas. ${ }^{48}$ Here the objective, as set forth in Professor Emerson's first premise, is to assure individual self-fulfillment. ${ }^{40}$

Recognizing these as the major objectives of the First Amendment, , $^{\text {ro }}$ the question for me is how these objectives can best be realized and given the maximum protection in a society which, in my opinion, does not hold freedom of expression to be a "good in itself." The soundness of any legal theory, I would submit, must be evaluated with this consideration in mind. The expression-action formulation, it would seem, would go a long way toward meeting the goal of full protection with respect to the public information and individual self-fulfillment objectives. While there may be hostility on the part of government officials and judges to the expression of unorthodox ideas, freedom of expression is enough of an "officially-approved" value in the society so that they are likely to be responsive to the argument that the expression of unorthodox ideas-as long as this is all that is involved-should not be suppressed. To put it another way, if the expression-action formulation as developed by Professor Emerson were to be adopted as the test of limitation by the Supreme Court, state court and lower federal court judges would, for the most part, probably "accept" it,

\section{P. 7 .}

46. P. 6 .

47. Using this analysis in the area of "group legal services," a case such as N.A.A.C.P. v. Button, 371 U.S. 415 (1963), would involve the dissent and social change objective, while cases such as Brotherhood of R.R. Trainmen v. Virginia, 377 U.S. 1 (1964), and United Mine Workers of America v. Illinois State Bar Association, 389 U.S. 217 (1967), would involve the individual expression and association objective.

48. Even if those ideas would otherwise be considered "hard core pornography." See Stanley v. Georgia, 394 U.S. 557 (1969).

49. See p. 6.

50. I would also analyze academic freedom as a separate functional component, em: bodying all three of the objectives. Professor Emerson would not treat academic frecdom as an "independent right." See his discussion at pp. 611.16. 
and apply it in the "public information" and "individual self-fulfill. ment" areas. While I think that these objectives would be better served by the approach that I will be advocating, I feel that they would be adequately protected under the expression-action formulation.

Where my serious reservations about the effectiveness of the expression-action formulation come in is with respect to the dissent and social change objective. Stated simply, I question the commitment of most government officials and of many state and federal judges to this objective in practice. Since we have generally thought of the courts as protecting freedom of expression from restrictions imposed by government officials, the attitude of the judges toward the dissent and social change objective becomes crucial. While I base the conclusion of "lack of judicial commitment" in no small part on my own experience, it is equally demonstrated by the "judicial behavior" that is reflected in court decisions involving expression directed toward dissent and social change. Let me elaborate on my reasons for this "heresy."

Judges are generally an integral part of what has come to be called the "Establishment." I use the concept of "Establishment" as a loose term representing a combination of power and attitude, power in the sense of "the people who are running things," and attitude in the sense of an essential satisfaction with the status quo and resistance to fundamental political, economic, or social change.51 Using the power and attitude criteria, not every judge is a part of the "Establishment," 32 but $I$ think it is safe to say that the overwhelming majority of them are. One usually becomes a judge in this country only after and because of substantial involvement in the political process, and this holds true for federal as well as state court judges. While federal judges are not subject to the same direct political pressures as their state court counterparts, who frequently must run for reelection, they are still part of the "political establishment" and are subject to its personal and social pressures. ${ }^{53}$ More significantly, they are likely to believe in the "system" which they have served and by which they have been rewarded. Persons who strongly dissent from that "system" and

51. See the discussion in Sedler, Book Review, 59 Kr. L.J. 578, 5834 (1971).

52. Justice Douglas, of course, is the prime example of one who is not. On the other hand, Justice Marshall has said that "[W]hen black students confront him-is they often do-with the charge that he is just a tool of the Establishment, he tells them that they had better wake up to the fact that 'I am the Establishment.' " Yale Daily Nevs, April 28, 1970, at 2, col. 3. Those who have the "Establishment" attitude, but not the power, an best be considered as "supporters of the Establishment," or what Presidene Nixon and Trare Mragazine have called the "silent majority."

53. See the discussion in Sedler, supra note 43, at 254. 
who actively work to achieve fundamental social change are not likely to become judges.

While the present social-economic-political system has brought to power persons whose values are likely to be wealth-oriented and essentially conservative, I do not think that the attitude toward dissent and social change would necessarily be different if a "peaceful revolution" were to take place and the reins of power were transferred to those whose values are socialistic and radical. The judges of a new "Establishment" may be no more disposed toward tolerating "counterrevolutionary" dissent and efforts at social change than their counterparts in the present system are toward tolerating that which is "revolutionary." 5 In short, if the dissent and social change objective is to be protected, it is necessary to take account of the attitudes toward dissent and social change on the part of those administering the legal system, and those attitudes cannot be expected to be favorable no matter what the social-economic-political complexion of the society may be. While my "input" in this regard comes from observing the system as administered by the "Establishment right," I am willing to assume-and believe I must if my goal is to maximize the freedom to dissent and work for social change-that the same problem will exist if the system is administered by an "Establishment left."

The paradox, then, is that if the dissent and social change objective of the First Amendment is to be effectively protected from governmental interference, it is the judges who will have the primary responsibility to do so, and they are an integral part of the very "system" toward which the dissent and social change effort is directed. In a sense they are being asked to go against their own self-interest and to protect the freedom of others to bring down that "system" of which they are a part and in whose values they believe. The paradoxical nature of the process by which legal protection is to be afforded to dissent and social change effort may explain why even the Supreme Court has been unable to develop a comprehensive theory of the First Amendment. It may help to explain the "straining" and "twisting" of legal principles that was necessary to uphold the convictions of the Communist Party

54. As to "New Left" views on the value of freedom of expression, sce Professor Emer: son's discussion at $\mathrm{pp}$. 723-28. My own discussions with younger "New Left" pcople-and I should add that politically I consider myself a part of the "New Left"-about frectom of expression have caused me some dismay, particulaxly when they make trguments such as "certain kinds of expression (support of the Vietnam War) are so immoral that they cannot be tolerated," and "repression by definition exists only in a capitallstlc system," so that the imprisoning of "counterrevolutionary" writers in the Soviet Union does not constitute repression. 
leaders in Dennis ข. United States. ${ }^{65}$ You cannot, as I recall a political science professor in college saying, "educate a man too far beyond the confines of his belly," nor can you expect him always to be willing to "sacrifice individual and short-term advantage for social and long-range goals"56 - particularly if he does not really believe in the social and long-range advantage.

If this is so, it means that the freedom to dissent and work for social change will never be fully protected by the courts no matter what legal theory is adopted, ${ }^{57}$ because judges, being human and subject to all the frailties and weaknesses of human beings, ${ }^{68}$ have the motivation to limit such protection, and given the opportunity will, consciously or unconsciously, try to do so. The real question becomes whether it is possible to maximize the protection that the courts will give, by structuring things in such a way that the judges can be "persuaded" to act contrary to their motivation and seeming self-interest.

This brings me to what I call "manipulating the system" and "influencing its behavioral component." The movement lawyer, or any other lawyer who has had some experience defending the "unpopular cause" or trying to protect dissent and efforts at social change, has long been disabused of the notion of the "neutrality of the law." He frequently perceives a case as a contest between himself on the one side and the judge or judges on the other, with the opposing lawyer playing a decidedly secondary role. ${ }^{59}$ The "game theory" in this contest seems to me to be "forcing the judge to face up to the contradictions," and the game works like this. Part of the "conventional wisdom" and the "officially-approved values" is that freedom of expression is a "good in itself," and the courts have the responsibility to protect it. This freedom of expression guarantees the right to dissent and to work for social change. The Constitution (with all the historical and emotive connotation that this word invokes) protects the conduct in question in the particular case precisely because that conduct involves dissent and efforts at social change. The hope is that the role perception of

\footnotetext{
55. 341 U.S. 494 (1951).

56. P. 10.

57. This is apart from the fact that judicial protection of constitutional rights as such can never be fully effective because of the limitations necessarily inherent in the enforcement porwers of courts, and the fact that they must resolve issues on a case-to-case basis.

58. Legal education tends too often to ignore the "behavioral and human" component of the system. In theory judges are "fungible," and if the "law" is properly fed into the machine the result will be the same no matter who the judge is. The student is soon dis. abused of this notion when he graduates or participates in a clinical program.

59. As an opposing lawyer once said to me following my ususl "heated colloquy" with a federal judge, "Boy, I sure wish I made the arguments that he did."
} 
"judge, whose duty it is to uphold the Constitution" will break through and will overcome the motivation, conscious or unconscious, to suppress dissent and efforts at social change, thereby resulting in a favorable decision.

The most important ingredient in this game is "the law." "0o To the extent that the "law" is clearly on the side of protecting dissent and efforts at social change, the judge's room for maneuver is lessened; he cannot in his own mind, and consistent with his role perception, 1 rationalize a decision denying protection. To the extent that legal principles are "subject to interpretation" or the precedents are ambiguous or conflicting, the room for maneuver is increased, and the judge is in a better position to come up with an "intellectually respectable" decision denying protection. ${ }^{62}$ From the movement lawyer's standpoint, then, the game is played primarily by forcing the judge "into a box," where he cannot intellectually reconcile the result he wants to reach-which is to deny protection -with the result that he believes the "objective application of the law" requires.

The above analysis is obviously oversimplified. It does not apply to those judges who may be "playing a different game," have consciously faced up to the contradiction and have come down on the side of the right to dissent and work for social change, or to those few who are themselves "dissenters." Nor will it work with those judges who will not "play the game," and who will deny protection with "malice aforethought" and with total indifference toward the possibility of reversal. But in most cases the "game" can be played, and must be played if dissent and efforts at social change are to receive legal protection. And as I have said, the most important ingredient in this "game" is "the law," or rather, the scope of manipulation and interpretation which "the law" is believed to allow.

With this in mind, I come back to Professor Emerson's observation that any exceptions to the system of freedom of expression must be "clear-cut, precise and readily controlled." $\mathrm{e4}$ I fear that as applied to the dissent and social change objective of freedom of expression, the

60. Another ingredient, of course, is the factual situation presented in the particular case. Where the conduct of the government officials has been "exceptionally raw" or when a severe sanction has been imposed or threatened, the likelihood of protection may be substantially increased.

61. This may or may not include a fear of reversal by higher courts,

62. As noted above, the judge will ordinarily be motivated to deny protection unless other factors such as "exceptionally raw conduct" are present.

63. "Different games" may relate to the judge's own personality and the kind of gratifi. cation he receives from his role.

64. P. 10 
expression-action formulation will not meet the test. In the hands of lower federal court and state court judges it leaves too much room for maneuver. Except in the "pure speech" situation, it requires an initial determination of the nature of the conduct and a classification of that conduct into "expression" or "action." The motivation of the judge will likely be to classify it as "action," and because there will be some "act" other than speaking or dissemination, it may be "intellectually possible" for him to do so. Professor Emerson would classify draft card burning, for example, as "expression," but I doubt if most judgesstung by the insolence of the defiance and probably remembering their own "World War II days"- would agree. There is enough of "speech plus" in the conduct to make an "action" classification "intellectually justifiable." Thus, unless there were a higher court precedent directly in point-which is the "trump card" in the game-the judge could with "justifiability" achieve the result he wanted, which would be to classify the conduct as "action." In any event, the opportunity for initial classification (with perhaps the implicit burden on the proponent to show that his activity was "expression") and the call for a "two-category judgment" ${ }^{\prime \prime s}$ increase the judge's maneuverability considerably.

The point I am trying to make is that if the protection of expression in the context of its dissent and social change objective is to be maximized, the expression-action formulation is not the best way to go about it. If the judge's maneuverability is to be limited, if he must constantly be made to confront the contradiction between the "officially approved" value of freedom of expression and his own likely opposition to dissent and social change, if he cannot have the role perception of "judge" unless he protects expression, he must not be given the "power to interpret" and the opportunity initially to classify the conduct as "expression" or "action." Instead, the "law" must be that there is full protection to all communication of ideas in any form whatsoever, and any exceptions to this principle must be just that-exceptions-with the explicit burden on the judge or the opponent of expression to fit the particular conduct into one of the exceptions. The "psychological shifting" of the burden, I think, is very important. The proponent

65. The classification must be either "expression" or "action," and there is no opportunity for an intermediate classification. It is analogous to a judgment of "guilty" or "not guilty" of a particular charge, which does not allow for compromise, and which cannot reflect the reservations that may be present in the mind of the person making the judg. ment. As to the "two-category judgment," see D. Jounson, Tre Psrciolocx of Tuovarr AND JUDGMENT 326 (1955). 
would not have the burden of establishing his conduct as "expression." Rather, once it appeared that the communication of ideas was involved in any way, the particular conduct would necessarily be entitled to protection unless the judge could establish to his "intellectual satisfaction" (and where appropriate, to the possible satisfaction of the appellate court) that it came within one of the narrowly-defined exceptions.

What I am trying to do is to take Professor Emerson's basic thesiswhich I fully accept-and change the operational test from the expression-action formulation to one of "full protection with limited exceptions." Because of my agreement with the basic thesis of the book, but my reservations about the efficacy of the expression-action formulation in the "world" in which freedom of expression must survive, I want to try to develop a test of "full protection with limited exceptions," which I would substitute for Professor Emerson's formulation.

At this point in time I cannot know whether such a test would be viable, and I have not considered all of its implications. Obviously, I have not developed it except in a preliminary way. I am not sure what all the limitations should be and of the possible consequences of recognizing particular limitations. I am not even certain that I have an underlying rationale for a scheme of limitations. I do think, based largely on the "view from within," that full protection with limited exceptions will be more effective than the expression-action formulation in protecting expression in the dissent and social change context, and possibly in the other functional areas as well. I do think that such a test will give the judges less maneuverability and make it intellectually more difficult for them to deny protection. Most importantly, I think that it will strengthen the hand of the proponents of dissent and social change and of their lawyers, and as I have said, this is the perspective-and bias-from and with which I am proceeding.

What follows must be understood to be only a very tentative formulation and subject to revision upon further reflection and research. $I$ start off with the proposition that: "The communication of any idea by any person in any form whatsoever is protected by the First Amendment unless that communication comes within certain designated and limited exceptions to which protection is not extended." I have come up with some of these exceptions, which, as I have said, are by no means complete, and which may suffer from a lack of a clear underlying rationale. The rationale is not that every exception is necessary to protect societal interests that are deemed more important than even freedom of 
expression, although in some cases this is true. Nor is it that with respect to every exception the communication of the idea could be achieved as well by means that would not entrench on other societal interests, although this too is true in some cases. Perhaps the rationale for the exceptions represents more than anything else a combination of these reasons on some kind of sliding scale. In any event, I have come up with eight exceptions that I believe to be sufficiently "limited" so that they may satisfy Professor Emerson's criteria of "clear-cut, precise and readily controlled" better than the expression-action formulation.

One: The First Amendment does not protect violence committed against other human beings or direct physical interference with their movement. Ideas, of course, can be communicated by violence, sometimes most effectively. This exception does represent a value judgment that bodily integrity is sufficiently important that it cannot be invaded even for the purpose of communicating an idea. The qualification of "direct physical interference with their movement" is designed to limit the restriction to the area of actual rather than hypothetical interference and to recognize that society may have to suffer some "inconvenience," even with physical movement, so that expression can be protected. ${ }^{66}$ Phrasing the exception in this way avoids the necessity of determining whether the "dominant aspect" of the conduct is "expression" or "action." If the conduct does not amount to violence or direct physical interference with movement, it simply does not come within the exception. This exception does not preclude the state from imposing reasonable and non-discriminatory limitations as to time, place and manner upon the conduct of demonstrations and the like or the use of public facilities. ${ }^{67}$

Two: The First Amendment does not protect serious destruction of property. Serious destruction of property is simply, in my view, not the way to go about expressing ideas in a democratic society. Destruc-

66. In O'Leary v. Commonwealth, 441 S.W.2d 150 (Ky. 1969), four students were conducting a "sit-in" at the placement office to protest against military recruitment. They sat in front of the door with their legs outstretched so that anjone coming into the room would have to step over. They were arrested before anyone came, and I argued that the "burden" of stepping over their outstretched legs was an "inconvenience" that had to be "suffered" in order to protect expression, drawing an analogy to the "littering" in Schneider v. State, 308 US.S. 147 (1939). The court never reached this question, holding that the students could be excluded from the building because "their privilege to be there was subject to the will of the university governing authorities."

67. See generally Professor Emerson's discussion at pp. 359.73. Time, place and manner limitations proceed upon a principle of "fair accommodation of opposing interests," designed to avoid conflict in the allocation of public facilities between expression and the other uses to which they may be put. 
tion of an individual's property may provoke retaliation, and so long as a society recognizes "property rights," it does not seem fair that one person's property should be destroyed so that another can express his ideas. The qualification of "serious" is designed to prevent the application of technical trespass and general "destruction of property" laws to minor acts which cause no real damage.

Three: Communications designed to produce or clearly having the effect of producing harmful consequences due to conduct on the part of others are not protected by the First Amendment. This is a hard one, and I am not particularly satisfied with its formulation. I am trying to include here the proverbial "cry of fire in a crowded theater," 68 the use of "fighting words" in a one-to-one situation likely to provoke retaliation, ${ }^{69}$ one-to-one solicitation to commit a crime, ${ }^{70}$ participation in riots or illegal action by "verbal commands"7t and similar conduct that Professor Emerson would clearly classify as "action." I am fearful that this exception may be formulated too broadly and that it might be used to uphold, for example, "incitement" prosecutions against "inflammatory speakers." I think I am prepared to say that in that situation the communication should be protected unless the harm in fact results and is clearly traceable to the communication.

Four: Direct interference with another person's exercise of First Amendment rights is not protected by the First Amendment. The purposes of the First Amendment are necessarily frustrated if those who are "stronger and louder" can overwhelm their opposition. This ex. ception would prevent disruptive acts such as drowning out the speaker or physically removing him from the platform. It would not prohibit "annoyances" such as heckling or picketing the speaker. This exception is in part related to the "time, place, and manner" limitation, in that it is designed to insure that all persons and groups have the same opportunity for the public expression of their views.

Five: Physical interference with governmental or organizational proceedings or intrusion upon such proceedings that makes their continuation impossible is not protected by the First Amendment. My formulation of the exception in this way is designed to invalidate

68. See Schenck v. United States, 249 U.S. 47, 51 (1919).

69. See Chaplinsky v. New Hampshire, 315 U.S. 568 (1942), and Professor Emcrson's discussion at p. 338 .

70. See the discussion at p. 405 .

71. See the discussion at pp. 328-86. As I indicated earlier, I may have some disagree ment with Professor Emerson's specific applications. 
restrictions on "picketing near the courthouse" and the like. The communication of ideas could not be restricted except at the point where there was a willful attempt to stop the proceedings from taking place. I would also be willing to recognize some restrictions on communication inside a courtroom while a trial is taking place or in a legislative chamber. But the major thrust of this exception is to recognize that only the actual disruption of proceedings is beyond the pale.

Six: The First Amendment does not protect the willful infliction of psychic injury on another, unless there is a clear public interest in the subject matter of the communication. Professor Emerson has demonstrated most cogently how it is possible to accommodate both the interest in expression and the interest in privacy by recognizing a zone of personal privacy where even expression cannot intrude. ${ }^{72} \mathrm{He}$ also points out that the primary interest to be protected in the defamation sphere is the "psychic one,"73 and concludes that the "privacy principles" are applicable here as well..$^{74}$ This zone of personal privacy in his view protects "only the most inner core of the personality, involving the kind of intimate details of personal life that were the Court's concern in Griswold v. Connecticut, ${ }^{75}$ where the constitutional right to privacy was born." 76 My sixth exception addresses itself to this matter. I would probably expand Professor Emerson's zone of privacy, focusing on the psychic injury rather than on the "intimate details," but the theory is the same-the interests of privacy and expression can be accommodated by recognizing a limited zone of privacy from which expression can be excluded. However, I would also allow for breaching the zone of privacy in certain cases of clear public interest, such as communications involving the personal life of public officials and candidates for public office.

Seven: Vialation of an individual's spatial privacy is not protected by the First Amendment. This recognizes that a person has a right to escape anything, even expression, by retreating into a zone of spatial privacy. This would, for example, protect a government official inside of his home. ${ }^{77}$ Note that the exception is framed in terms of individuals. It does not mean that protestors can be excluded from buildings

72. See pp. 544-50.

73. P. 543. See also Probert, Defamation, A Camouflage of Psyehic Interests: The Beginning of a Behavioral Analysis, 15 VAND. L. REv. 1173 (1962).

74. P. 543 .

75. 381 U.S. 479 (1965).

76. P. 556 .

77. But not from demonstrations in the vicinity of his home. Cf. Gregory v. City of Chicago, 394 U.S. 111 (1969). 
on the ground that they are invading "spatial privacy." Such protests could be regulated only under the fifth exception (if they disrupted proceedings) or under a reasonable time, place and manner limitation.

Eight: Communications in the commercial sector of society are subject to regulation appropriate to that sector. The commercial sector of society is "crudely defined" by Professor Emerson as embracing "the production and exchange of goods and services for profit, as distinct from the production or exchange of ideas on political, religious, artistic and similar matters." 78 In Professor Emerson's view communications in this area are outside the system of freedom of expression, which means that different legal rules may be required to determine the application of the First Amendment. ${ }^{70}$ The distinction between commercial and non-commercial expression is "well-established in our constitutional law," 80 and I am willing to accept it. However, the fact that expression may be somehow related to commercial activity does not put it into the commercial sector for purposes of this exception. Picketing or a consumer boycott, for example, to protest a company's discriminatory hiring policies or its polluting the atmosphere would be fully protected. ${ }^{81}$ It is only the "commercial communication" itself, i.e. a communication made in connection with the production or exchange of goods and services by the producer or seller or a competitor, that is subject to appropriate commercial regulation.

It is these eight exceptions, subject to modification or addition, that would constitute the "exceptions" part of my "full protection with limited exceptions" approach. There is very little, if any, difference in the results that I would reach under this approach and the results that Professor Emerson would reach under the expression-action formulation. It is my submission, however, that in actual operation, there would be a significant difference in result under the expression-action formulation to the detriment of freedom of expression in its dissent and social change objective, because the expression-action formulation gives the courts more "intellectual" maneuverability, and given such maneuverability, I think that they would yield to the temptation to suppress unorthodox expression.

I want to emphasize that the "full protection with limited exceptions" approach is predicated upon my acceptance of Professor Emerson's basic thesis and the system of freedom of expression that he

78. Pp. 414-15.

79. See pp. 19-20.

80. P. 415 .

81. See Professor Emerson's discussion at pp. 448-49. 
has developed. I would change only the operational test, because I believe that the test I have proposed will be more effective to protect the dissent and social change objective of freedom of expression in practice. This belief is based on my view of the system of expression "from without and within" and of the "world" in which it must survive.

If a primary function of scholarship is to influence the thoughts of others and to lead them into their own "search for truth," the experience of reading The System of Freedom of Expression has served that function for me. The System of Freedom of Expression represents Professor Thomas Emerson's unique and invaluable contribution to legal thought in the area of First Amendment rights. He has indeed developed a system by which the meaning of those rights can be fully understood and explored further. The book reflects both his lifetime commitment to libertarian values and to the law as a means of implementing those values. It will serve as an inspiration to those who choose to follow in his path. 
